\title{
Refugees, Humanitarian Emergencies, and the Politicization of Life
}

\author{
Peter Nyers
}

\begin{abstract}
The concept of "humanitarian emergency" has come to be largely synonymous with contemporary refugee situations. The purpose of this paper is to critically explore the connections between the categorization of refugees as an "emergency" situation and the way in which "humanitarianism" has come to constitute a hegemonic discourse in which academics, policy-makers, international organizations, and refugee advocates must formulate their arguments and actions. Humanitarianism is often portrayed as posing a challenge to the codes and practices of state sovereignty because it is a form of action which is purportedly motivated by a sense of obligation and responsibility to "humanity" that goes beyond the responsibility one feels for fellow citizens. This paper analyzes a series of recent UNHCR representations of refugees to suggest that humanitarianism must instead be understood as an inherently political concept. Drawing upon the writings Giorgio Agamben, this paperdemonstrates how humanitarianism is always already (bio)political to the extent that it relies on a conception of "bare human life" which is consistent with the practices of state sovereignty. From this perspective, framing the refugee phenomenon as a "humanitarian emergency" works to sustain constitutive practices which stabilize and reproduce statist resolutions to questions of political identity, community, and world order.

\section{Précis}

Le concept d' «urgence humanitaire» est devenu une sorte de synonyme général de «situation contemporaine des réfugiés». Le but de cet article est de procéder à une exploration critique des liens entre la catégorisation du refuge comme situation

Peter Nyers is a Ph.D. candidate, Department of Political Science, York University, Toronto, Canada. $d^{\prime}$ «urgence» et la façon dont l'idée $d$ '«humanitarisme» en est venue dे se constituer en discours hégémonique, dans le cadre duquel les universitaires, les décideurs, les organisations internationales, et les défendeurs des droits des réfugiés se voient obligés de formuler leurs arguments et leurs actions. L'humanitarisme est souvent dépeint comme posant un défi aux codes et pratiques de la souveraineté des états, car c'est une forme d'action qui serait motivée par un sens de la responsabilité et des obligations enversl' «humanité» quioutrepasserait les responsabilités que l'on aurait envers ses concitoyens. Le présent article analyse une récente série de représentations de réfugiés du HCR visant a suggérer que l'humanitarisme devrait plutôt être compris comme in concept fondamentalement politique. Fondé sur les écrits de Giorgio Agamben, le présent article démontre comment l'humanitarisme est toujours déjà (bio)politique dans la mesure où il se fonde sur une conception de la «vie humaine minimale» qui est conformeà les pratiques des états souverains. Dans cette perspective, formuler le phénomène du refuge en terme $d^{\prime}$ 'urgence humanitaire» tend d perpétuer des pratiques constitutives quistabilisent et reproduisent la résolution étatiste des questions d'identité politique, de communautés, d'ordre mondial.

\section{A Crisis Vocabulary}

The phenomenon of the refugee has a long history of being subsumed within discourses of crisis and danger. Words such as problem, crisis, "complex emergency," challenge, and controlare commonly invoked when the subject of refugees and their movements arise. Refugee situations today are usually provoked by a complicated configuration of political, socio-economic, and environmental forces which have conjoined to create to a crisis situation. The suddenness and severity of post-Cold War refugee flows has prompted a prominent UNHCR official to characterize these situations as "mega-crises" in a statement to the UN Security Council (Jessen-Petersen 1998, 65). It is thereforenot surprising to find that " $\mathrm{hu}$ manitarian emergency" has come to be one of the most popular concepts in the refugee studies literature, dominating the vocabulary of the officials, aid workers, advocates, academics, and journalists. The concept attains further credibility for the way it connects the urgency of crisis situations with a heightened sense of moral obligation for individuals and groups caught in such situations. This emphasis on ethical responsibility is especially pertinent given the recentchanges to the immigration and refugee policies of Western states, where increased restrictions, tightened procedures, and shortened time-lineshavedrastically undercut the asylum cultures of these countries (Carlier et al., 1997). These changes, moreover, come at a time when both the number of refugees and crisis situations are proliferating. Indeed, the 1.5 million refugees the UNHCR recognized in 1951 had increased to 13.2 million by 1996, together with an additional 8.5 million internally displaced persons, returnees, and others of concern to the agency (UNHCR 1997). The financial costs of providing humanitarian assistance and protection to refugees has similarly increased: the UNHCR's original budget of U.S. $\$ 300,000$ has been dwarfed by recent budgets in excess of some U.S.\$1.3 billion (Cunliffe 1995).

The problem of refugees, however, does not lie in their numbers alone. It is a problem, first and foremost, of categorization, of making distinctions. All classifications have social conditions for their production and historical circumstances which make them credible. ${ }^{1}$ However, the immediacy-indeed, the "emergency" - of refugee situations has left little time for critical 
self-reflection on the conditions and circumstances that make such a system of discrimination possible. Daniel Warner $(1995,372)$ speaks to this point when he recalls the reaction of the High Commissioner of the UNHCR to an academic exegesis of refugee discourse: "That was all very well Professor, but what am I todowith the problem tomorrow morning?"

One of the enduring consequences of being defined in crisis terms is that the refugee phenomenon, not surprisingly, has been typically incorporated into what Robert Cox (1996) has identified as "problem solving" discourses-an approach which is generally practical and operational in nature, and where a short-term, crisis-oriented attitude is encouraged. As Cox recognized, however, the major concern with "problem solving" perspectives-and I would add, especially when they operate under the strict temporal constraints imposed by "emergency" situations-is that they invariably concentrate their attention on the practical ways in which order and normalcy can be reinstated. Critical questioning of both the unequal power relations and desirability of this order are de-emphasized, marginalized, or ignored. Also de-emphasized is any attempt to question the role of such key foundational concepts as citizenship and state sovereignty. Such critical questioning, however, seems to be crucial if we are to be in a position to identify and explain how refugees figure into debates about current and possible transformations of world order.

A useful way to begin such questioning is to think of emergencies as Walter Benjamin suggests. In his "Theses on the Philosophy of History," Benjamin $(1968,257)$ writes:

The tradition of the oppressed teaches us that the "state of emergency" in which we live is not the exception but therule. Wemustattain to a conception of history that is in keeping with this insight. Then we shall clearly realize that it is our task to bring about a real state of emergency ...

Benjamin's diagnosis of the "state of emergency" loses none of its relevance when it is applied to contemporary questions about humanitarianism, multilateral cooperation, and the global refugee crisis. Situations deemed emergencies are always interesting for how they reveal the often unquestioned and undertheorized assumptions about what constitutes a "normal" state of affairs. Consequently, to think of emergencies as "not the exception but the rule" means paying attention to those practices which work to reproduce and sustain prevailing conceptions of "normality" and "order."

What, then, is this "normal" state of affairs with respect to refugees? A 1939 review of international co-operation on the "refugee question" offers a conventional answer that is still relevant today. The author, an international lawyer, comments on how the refugeecondition should be understood as a temporary condition: "The status of the refugee is not, of course, a permanent one. The aim is that he [sic] should rid himself of that status as soon as possible" (Jennings $1939,98)$. The lawyer probably felt justified in so easily incorporating the phrase "of course" into his discussion because, as mentioned above, a crisis mentality prejudices one toward a shortened temporal horizon. His casual acceptance, however, can also be interpreted as a claim about the "proper" and "enduring" form of political identity and community - that is, the citizen and the nation-state. It is because the refugee is displaced from these "authentic" identities and communities that she is seen as no more than a temporary aberration to the norm, a hiccup which momentarily disturbs the "nationalorder of things." 2 But to assume that the concepts of "citizenship" and "sovereign state" are somehow unproblematic, foundational principles of modern political life is to engage in an act of reification which obfuscates the real, historical political practices of identity and community formation and contestation (Magnusson 1996). From this perspective, state sovereignty is not so much a thing, a static juristic principle to be invoked, as an effect of various practices. As such, state sovereignty should not be assumed so much as ex- plained. As Cynthia Weber $(1995,3)$ explains,

It is not possible to talk about the state as an ontological being - as a political identity-without engaging in the political practice of constituting the state. Put differently, to speak of the sovereign state at all requires one to engage in the political practice of stabilizing this concept's meaning.

If conventional perspectives on the refugeephenomenon work according to an emergency logic that blocks critical reflection on foundational assumptions, how is the identity of the refugee affected by such a discourse? What constraints and possibilities exist for individuals finding themselves labelled as refugees? In the nextsection I will examine how humanitarian assumptions work to further the aberrant status of refugees by examining some recent UNHCR visual representations of the refugee condition.

\section{Representing Refugees: Emptiness, Lack, Silence}

The first representation opens the UNHCR internet website of refugee images. ${ }^{3}$ This website sees itself as providing a visual supplement to the rather abstract legal definitions that are typically employed to explain the condition of the refugee. As such, its purpose is summed up by its title-What is it like to be a refugee? The ensuing photographs attempt toanswer this question. And so, on onescreen we see $\mathrm{Rw}$ wandan refugee family, fleeing the country with 250,000 others all on the same day in April 1994. On another, there is a photograph of an elderly Bosnian woman who has become 'internally displaced' within her own community. These photographsand others representing the struggles of Tajik, Somali, Vietnamese, and other refugees-reflecthow the recent proliferation in refugee numbers has been matched by an unprecedented polymorphism and complexity in the causes, underlying dynamics, and effects of global refugee flows. Consequently, viewing the visual archive can leave one with the sense that no simple or singular answer to the question of refugee identity (or "refugeeness") is possible. Cur- 
rent conditions strongly suggest that the answer to the website's initial question mustnecessarily be plural, ambiguous, and historical.

The diversity in the lived experiences of the refugees represented in the UNHCR's visual catalogue gives testament to the sheer scope and complexity of contemporary refugee flows. At the same time, however, the organization insists that behind these experiences born out of particular contexts and circumstances lies a common underlying identity which is universally shared among all refugees. This universalist, humanitarian perspective is well represented in the title page photograph. At first, the photograph seems to be a rather enigmatic choice for a title page representation. Noactual person-refugee or otherwise-can be found anywhere in the picture. Portrayed rather is a single long-sleeved shirt suspended in front of a make-shift shelter. The shirt, moreover, hangs in a way that produces the illusion that a human body - the body of the refugee-is occupying it. We expect to see the refugee, but that individual is missing, absent, invisible. However, the essential humanitarian message is clear-the emptiness of the shirt signifies the emptiness that all refugees feel when they are forced to sever their ties with their home. To the question "What is it like to be a refugee?" the conventional humanitarian answer is presented in terms of a profound sense of lack. Like the empty shirt, the life of the refugee is typically seen as suffering from emptiness. ${ }^{4}$

Such a perspective is also apparent in a second UNHCR representation found in the organization's most recent report, The State of the World's Refugees: $A$ Humanitarian Agenda (UNHCR 1997, 50). Each chapter of this publication has an accompanying photograph chosen for how it compliments and further conveys the chapter's central theme. The second chapter, entitled "Defending Refugee Rights," is monnied by a photograph of a Lankan refugee child in Tiruchi, India. The child is standing beside several large trunks, which hold, no doubt, the only possessions the child's family could transport during the flight from theirhomes. What is most striking.about the photograph is that its subject-the refugee child, standing behind a backlit curtain-can only be seen as a shadow. Absent is any indication of even the most basic physical features-not even the child's gender can be discerned. What is the significance of this? Why would a photograph chosen to illuminate the challenges of defending refugee rights present an anonymous, two-dimensional outline of a child's human form? Liisa Malkki $(1996,388)$ offers an interesting perspective, suggesting that "the visual prominence of women and children asembodiments of refugeeness has to do not just with the fact that most refugees are women and children, but with the institutional, international expectation of a certain kind of helplessness as a refugee characteristic." Consequently,just as the opening photograph of the UNHCR's website is notable for how it links "refugeeness" with invisibility, acorporeality, and emptiness, the image of the refugeechild is striking for how it effaces all traces of presence on behalf of refugees when it comes to discussing their political and social rights.

These humanitarian images of refugees, like all representations, cannot be expected to convey one thing as another without political effect. In a recent article, Malkki demonstrates how humanitarian representations of refugees act as an intervening force in world politics. Malkki notes how both the mass media and the publications of humanitarian and international organizations perform such a role, transforming refugees into what she calls "speechless emissaries."

One of the most far-reaching, important consequences of ... established representational practices is the systematic, even if unintended, silencing of persons who find themselves in the classificatory space of "refugee." That is, refugees suffer from a peculiar kind of speechlessness in the face of national and international organizations whose object of care and control they are. Their accounts are disqualified almost a priori, while the languages of refugee relief, policy science, and " $\mathrm{de}$ - velopment" claim the production of authoritative narratives about refugees. (ibid., 386)

Humanitarian representational practices, Malkki argues, attempt to disturb the common distinction between refugees and non-refugees by promoting a vision of a shared and common humanity. Such representations, however, often end up portraying an undifferentiated "raw" or "bare" vision of humanity which works to mask the individuality of refugees-as well as the historical and political circumstances which forced them to take this identity. Malkki argues that "in their overpowering philanthropic universalism, in their insistence on the secondariness and unknowability of details of specific histories and specific cultural or political contexts, such forms of representation deny the very particulars that make people something other than anonymous bodies, merely human beings" (ibid., 388-89).

One of the central difficulties of portraying refugees as "merely human beings" is that all notions of political agency are, in a word, emptied from refugee subjectivity. This type of analysis captures what is at stake politically with the refugee phenomenon: refugees are silent-or rather, silenced-because they do not possess the proper political subjectivity (i.e., citizenship) through which they can be heard. It is in this sense that the assumptions informing the humanitarian representations of refugees described above correspond to a form of discriminations Jacques Derrida(1976) has labelled logocentric. Briefly, logocentric distinctions are hierarchically arranged binary oppositions in which one privileged term (logos) provides the orientation for interpreting themeaning of the subordinate term. Refugees have been negatively defined as registering a two-fold lack with respect to the privileged resolutions to questions of political identity (citizenship) and community (nationstate). Whereas the citizen is firmly and , securely rooted in the sovereign territorial space of thestate, the refugee suffers

from displacement: she is uprooted, dislocated, an unwilling exile of the com- 
munity of citizens. Refugees therefore signify an emptiness, an incompleteness vis-à-vis the meaningful presence to political subjectivity thatstate citizenship provides. To rectify this crisis, multilateral actions attempt to enact a spatial reversal of the binary and transform this lack into a positive presence. Not surprisingly, these "solutions" take the form of restoring statist identities and communities to refugees in the form of voluntary repatriation (i.e., returning to country of origin) and asylum (i.e., settlemant and integration into another country) as well as encouraging multilateral cooperation on refugee issues.

\section{Humanitarianism and the Politicization of Life}

To say that humanitarian representations work to de-politicize refugee identity is to at once raise the entire question of humanitarianism's relationship to politics. In its modern guise humanitarian action has been consistently premised on the principles of humanity, impartiality, and neutrality. Pivotal instances in the spread of these humanitarian principles include Dunant's founding of the International Committee of the Red Cross (ICRC) in 1863, the adoption of the Hague Conventions in 1907 as well as the Geneva Convention of 1949 and its additional protocols of 1977. The current High Commissioner of the UNHCR, Sadako Ogata, emphasizes the contemporary relevance of these principles when she insists that the creation of "humanitarian space" must be "premised on the principles of impartiality and neutrality" and be "independent from political goals and considerations."

The principles of impartiality and neutrality, furthermore, gain their force from a prior distinction made between humanitarianism and politics. It is well known, for instance, that the humanitarian and social' disposition of the UNHCR (stipulated in Article II of its founding Statute) is articulated only after the agency's work is defined as "non-political." The president of the ICRC puts the issue bluntly in a 1992 address to the UN General Assembly: "humanitarian endeavor and political action must go their separate ways if the neutrality and impartiality of humanitarian work is not be jeopardized."

According to the conventional wisdom, therefore, humanitarianism is conceived as the opposite of political activity. The two constitute a hierarchical binary, the normative character of which has the former element carrying positiveconnotations ("humanitarianism is compassionate, principled, impartial") while the latter is seen in negative terms ("politics is cynical, amoral, self-interested"). This binary logic, moreover, is typically employed to explain the "cause and effect" of refugee flows: on the one hand, it is political activity gone too far which creates the problem of forced displacement; on the other, the effects of these flows raise humanitarian concerns and the need for humanitarian action (Cutts 1998, 3-5).

The idea that humanitarianism and politics can be somehow kept separate and distinct from one another has not gone unchallenged. ${ }^{7}$ There is a growing recognition for how the politicization of humanitarianism (intended or unintended) is undermining the ability of aid workers to act in a neutral and impartial manner (Minear and Weiss 1991). To be sure, in the context of conflict or crisis, the revered principles of neutrality and impartiality often simply come to be a matter of perspective. For example, humanitarian organizations invariably have to cooperate to some degree with governments and international organizations, yet their mere association with these bodies can damage the perception of neutrality. What is more, in cases where humanitarian emergencies occur within the context of a "policy vacuum," humanitarian aid workers are often left with no other choice but to fill this vacuum and become political actors themselves (Roberts 1996,51-54; Vogel 1996). Finally, as Mark Cutts $(1998,4)$ has noted, the extreme logistical challenges posed by crisis situations can lead to circumstances where "politically naïve humanitarian organizations are themselves the blame for obscuring the real issues of genocide, ethnic cleansing and other massive human rights abuses, by focusing too much on issues such as food and medical supplies."

The humanitarian-politics relationship, however, is much more complicated than provided for by the "politicization" criticism. This latter perspective often remains committed to a pure, non-political conception of humanitarianism which has not been spoiled by a negative interaction with political forces. Many scholars, however, have recently suggested that the principle of "humanity," which provides both thejustification and orientation of humanitarian action, must be re-conceived as an inherently political concept. For instance, the relationship between the principles of state sovereignty and humanity has been extensively explored in recent works by critical international relations theorists. In an important study, Andrew Linklater (1982) has characterized the development of international relations in terms of a moral conflict between claims to citizenship and claims to humanity. Does one place an obligation toward humanity and strive for ethical universality, or does one privilege the duties we have toward fellow citizens in a political association and therefore settle for ethical particularity? Themodern practice of international relations, Linklater argues, is predicated on the early modern trade-off between "men" and "citizens." The terms of this tradeoff, classically represented in the work of Thomas Hobbes (1968), stipulate that priority begiven to claims of citizenship in the particular political association of the state. Hobbes resolves the conflict between the universal and the particular by positing a theory of state sovereignty which allows for one international system with many particular states. Rob Walker $(1993,154)$ explains the logic of this citizen/human resolution:

As a response to questions about


somehow both, state sovereignty affirms that we have our primary-often over-riding-political identity as participants in a particular community, but retain a potential connection with 'humanity' through participation in a broader international system 
... As citizens, we may aspire to universal values, but only on the condition that we tacitly assume that the world out there is in fact a realm of particular states, of other communities each aspiring to some notion of goodness, truth and beauty.

The modern phenomenon of the refugee disturbs this resolution to the extent that it represents a conceptual, empirical, and physical breach in the relationship between "humans" and "citizens." Here, we should recall Malkki's analysis of humanitarian representations which present refugees in terms of a "naked" or "bare" visions humanity. The moral appeal of such conceptions of "humanity" gain force from the universal character of the shared "human existence" or "bare human life" that is common to all people. For the Italian critic and theorist Giorgio Agamben, however, it is precisely a human being's bare life-and not some social contract or an individual's free will-that functions as the foundation for the state's legitimacy and sovereign power: "from the point of view of sovereignty only bare life is authentically political" (Agamben 1998, 106). From this perspective, "humanity"-far from being a neutral conceptis seen to be inextricably connected to our modern understanding of the nature and location of "the political." Consequently, the principal reason refugees constitute a "problem" or "emergency" to the international system of states lies in "the very ambiguity of the fundamental notions regulating the inscription of the native (that is, of life) in the juridical order of the Nation-State" (Agamben 1996, 161). Thus, for Agamben, the refugee phenomenon is a problem which mustbe resolved not within some allegedly neutral "humanitarian space," but rather on the terrain of "biopolitics."

Foucault $(1978,143)$ employed the concept of "biopower" to refer to those forces which "brought life and its mechanisms into the realm of explicit calculations and made knowledgepower an agent of transformation of human life." Agamben applies this concept to Hannah Arendt's writings to demonstrate how refugees-repre- sented as bare human life--are caughtup in the "mechanisms and calculations" of sovereign power. Arendt entitled the chapter in Imperialism which addresses refugees, "The Decline of the Nation-State and the End of the Rights of Man." Agamben suggests we continue to take this formulation seriously for it correctly links "the fate of human rights with the fate of the modern Nation-State in such a way that the waning of the latter necessarily implies the obsolescence of the former" (Agamben 1996, 161). Individuals characterized by the absence of statist identities and communities (i.e., refugees) thus bring about a radical crisis to the allegedly eternal and universal concept of human rights. As Arendt $(1968,179)$ states,

The conception of human rights, based upon the assumed existence of a human being as such, broke down at the very moment when those who professed to believe in it were for the first time confronted with people who had indeed lost all other qualities and specific relationships-except that they were still human.

To explain how this paradox comes about, Agamben (1998, 128) suggests we need to appreciate the way the modern state makes nativity (i.e., birth, naked human life) the "bearer of sovereignty":

The principle of nativity and the principle of sovereignty [are] irrevocably united in the body of the "sovereign subject" so that the foundation of the new nation-state may be constituted ... The fiction implicithere is that birth immediately becomes nation such that there can be no interval of separation between the two terms. Rights are attributed to man (or originate in him) solely to the extent that man is the immediately vanishing ground (who must never come to light as such) of the citizen.

From this perspective, "humanity" is already present within the concept of citizenship; it appears as the "hidden difference" between birth and nation. Agamben's point is that refugees make what is hidden-i.e., bare life-come to light, thus "unhinging" the state-nation-territory trinity that conventional theories of the state take for granted. As the modern political imagination remains fixated on the citizen as the authentic ethico-political identity, it is not surprising that refugees (as the absence of that identity) are stripped of all political agency and deemed temporary, "emergency" situations. Indeed, Agamben $(1998,133)$ suggests that when humanitarian organizations portray refugees in the figure of bare human life they may "despite themselves, maintain a secret solidarity with the very powers they ought to fight." In the end, prevailing "solutions" to the refugee's plight focus on returning to refugees statist identities so as to restore the conditions under which they may once again enjoy a properly "human" life as citizens.

\section{Conclusion: Emergency or Emerging Identities?}

At the same time that refugees are defined in terms of a "humanitarian emergency" and thus as an object of ethical concern, they are also defined as a crisis in international order. Sadako Ogata $(1998,64)$ speaks to this point when she notes that humanitarian action "to bring protection and relief to the victims is of course a moral issue at its core, but can also have a strategic value in preserving regional and global stability." The wording of the High Commissioner's statement is worth reflecting upon for it points to a fundamental ambiguity that characterizes conventional multilateral responses to the phenomenon of global refugee flows: what is the relationship between a commitment to humanitarian action on the one hand, and to the principles and norms which underline the "peace, security, and stability" of the international system of states on the other? While the first commitment appeals to a common human identity as the basis for multilateral humanitarian action, the second directs our concern toward maintaining a world order which insists upon citizenship as the authentic ethico-political identity.

The modern account of the location and character of the political continues to be powerfully compelling. As this 
paper has tried to demonstrate, even actions residing on the limit of modern politics-such as humanitarian multilateral cooperation on the refugee problem-tend to be, in the end, overdetermined by the statist prerogative to claim the authentic subjects and spaces of politics as its own. The humanitarian ethic in these cases is subsumed within the logic provided by state sovereignty, a logic which already posits a resolution between the moral obligations we feel toward the one and themany, the universal and the particular, humanity and citizen-subjects.

Emergency discourses, however, cannot completely control or disarm political phenomena which challenge, exceed, or simply side-step the limits of modern accounts of political space and identity. Instead, as Homi Bhabha $(1994,41)$ has noted, the "state of emergency is also always a state of emergence." There is always some "political excess" which allows us to consider how a phenomena such as refugees can figure into the process of transforming world order by virtue of how they "contest borders, put states into question (without rendering them irrelevant), rearticulate spaces, and reform identities" (Campbell 1994, 368). Refugeesituations should therefore be understood as complex, multidimensional sites of identity practices. Refugee identity is not merely the negative, empty, temporary, and helpless counterpart to the positive, present, permanent, and authoritativecitizen. Weneed todevelop a perspective which is open to the possibility of political and ethical engagements which does not reproduce the sovereign codes which doom refugees to the status of "speechless emissaries" (Malkki 1996). Inspiration in this endeavour should obviously be encouraged especially when we are confronted with conventional perspectives on refugee flows which think that practical and operational "solutions" within a statecentric discourse are sufficient to understand this phenomenon. It is only once these claustrophobic imaginings of world politics are resisted, both in theory and practice, that we can begin seriously to consider what it might mean to bring about Benjamin's "real" state of emergency.

\section{Notes}

1. Compare: Foucault 1973; Bourdieu 1984; Butler and Scott 1992; Machiavelli 1979.

2. The phrase appears in Malkki 1992.

3. See:http://www.unhcr.ch/images/

4. For a parallel discussion of how the theme of emptiness is also found in representations of homeless people, seeKawash 1998.

5. Quoted in Cutts 1998, 10.

6. Quoted in Roberts 1996, 55.

7. A number of academic journals have recently dedicated special issues on the topic of the state and viability of humanitarianism today. See Refugee Suroey Quarterly 17 , no. 1 (1998); Disasters 22, no. 4 (1998); Millennium: Journal of International Studies 27, no. 3 (1998).

\section{References}

Agamben, Giorgio. 1996. "Beyond Human Rights." Trans.CesareCasarino. In Radical Thought in Italy: A Potential Politics, edited by Paolo Virno and Michael Hardt. Minneapolis: University of Minnesota Press.

-1998. Homo Sacer: Sovereign Power and Bare Life. Trans. Daniel Heller-Roazen. Stanford: Stanford University Press.

Arendt, Hannah. 1968. The Origins of Totalitarianism. Vol. 2, Imperialism. New York: Harvest.

Benjamin, Walter. 1968. Illuminations. Trans. Harry Zohn. New York: Schocken Books.

Bhabha, Homi K. 1994. The Location of Culture. New York: Routledge.

Bourdieu, Pierre. 1984. Distinction: A Social Critique of the Judgement of Taste. Trans. Richard Nice. Cambridge, MA: Harvard UniversityPress.

Butler, Judith, and Joan W. Scott, eds. 1992. Feminists Theorize the Political. New York: Routledge.

Campbell, David. 1994. "Political Excess and the Limits of the Imagination." Millennium: A Joumal of International Studies 23, no. 2, 365-75.

Carlier, Jean-Yves et al., eds. 1997. Who is a Refugee? A Comparative Case Law Study. The Hague: Kluwer Law International.

Cox, Robert W. 1996. "Social Forces, States, and World Orders: Beyond International Relations Theory." In Approaches to World Order, edited by Robert W. Cox and Timothy Sinclair. Cambridge: Cambridge University Press.

Cunliffe, Alex. 1995. "The Refugee Crisis: A Study of the United Nations High Commission for Refugees." Political Studies 43, no. 2, 278-90.

Cutts, Mark. 1998. "Politics and Humanitarianism." Refugee Survey Quarterly 17, no.1, 1-15.
Derrida, Jacques. 1976. Of Grammatology. Trans. Gayatri Chakravorty Spivak. Baltimore: John Hopkins University Press.

Foucault, Michel.1973. The Order of Things: An Archaeology of the Human Sciences. New York:Vintage.

- 1978. The History of Sexuality. Vol. 1, An Introduction. Trans. Robert Hurley. New York: Vintage Books.

Hobbes, Thomas. 1968. Leviathan. Edited by C. B. Macpherson. New York: Penguin.

Jennings, R. Yewdall. 1939. "Some International Law Aspects of the Refugee Question." The British Yearbook of International Law, no. 20, 98-114.

Jessen-Petersen, Soren. 1998. "Statement to the Security Council by Soren JessenPetersen, UNHCR." Refugee Survey Quarterly 17 , no. $1,65-68$.

Kawash, Samira. 1998. "The Homeless Body." Public Culture 10, no. 2, 319-39.

Linklater, Andrew. 1982. Men and Citizens in the Theory of International Relations. London: MacMillan Press.

Machiavelli, Niccold. 1979. The Prince. New York:Penguin.

Magnusson, Warren. 1996. The Search for Political Space. Toronto: University of Toronto Press.

Malkki, Liilsa H. 1992. "National Geographic: The Rooting of Peoples and the Territorialization of National Identity Among Scholars and Refugees." Cultural Anthropology 7 , no. 1, 24-44.

_.1996. "Speechless Emissaries: Refugees, Humanitarianism, and Dehistoricization." Cultural Anthropology 11, no. 3,377404.

Minear, Larry and Thomas G. Weiss. 1991. "DoInternational Ethics Matter? Humanitarian Politics in the Sudan." Ethics and International Affairs 5, 197-214.

Ogata, Sadako. 1998. "Humanitarian Action in Conflict Situations: Statement by the High Commissioner.". Refugee Survey Quarterly 17 , no. 1, 60-64.

Roberts, Adam. 1996. Humanitarian Action in War. Adelphi Paper no. 305.

UNHCR. 1997. The State of the World's Refugees: A Humanitarian Agenda. New York:Oxford University Press.

Vogel, Tobias. 1996. "The Politics of HumanitarianIntervention." Journal of Humanitarian Assistance, 3 September.

Walker, R. B. J. 1993. Inside/Outside: International Relations as Political Theory. Cambridge: Cambridge University Press.

Warner, Daniel. 1995. "Constructing a Productive Other" [Book Review]. International Journal of Refugee Law7, no. 2,371-74.

Weber, Cynthia. 1995. Simulating Sovereignty: Intervention, the State and Symbolic Exchange. Cambridge: CambridgeUniversity Press. $ם$ 